\title{
Bactericidal effect of iron oxide nanoparticles on Staphylococcus aureus
}

This article was published in the following Dove Press journal:

International Journal of Nanomedicine

8 April 2010

Number of times this article has been viewed

\author{
Nhiem Tran' \\ Aparna Mir ${ }^{2}$ \\ Dhriti Mallik ${ }^{2}$ \\ Arvind Sinha ${ }^{2}$ \\ Suprabha Nayar ${ }^{2}$ \\ Thomas J Webster ${ }^{3}$ \\ 'Department of Physics, Brown \\ University, Providence, Rhode \\ Island, USA; ${ }^{2}$ Department of \\ Materials Science and Technology, \\ National Metallurgical Laboratory, \\ Burmamnines 831007, Jamshedpur, \\ India; ${ }^{3}$ Division of Engineering and \\ Department of Orthopedics, Brown \\ University, Providence, \\ Rhode Island, USA
}

Correspondence: Thomas JWebster Division of Engineering and Department of Orthopedics, Brown University, Providence, RI 02912, USA

$\mathrm{Tel}+\mathrm{I} 4018632318$

$\mathrm{Fax}+\mathrm{I} 4018639107$

Email thomas_webster@brown.edu
Abstract: In order to study the effects of iron oxide (IO) nanoparticles on Staphylococcus aureus, IO nanoparticles were synthesized via a novel matrix-mediated method using polyvinyl alcohol (PVA). The IO nanoparticles were characterized by transmission electron microscopy and dynamic light scattering. Further, $S$. aureus were grown in the presence of three different IO nanoparticle concentrations for four, 12, and 24 hours. Live/dead assays were performed and the results provide evidence that IO/PVA nanoparticles inhibited $S$. aureus growth at the highest concentration $(3 \mathrm{mg} / \mathrm{mL})$ at all time points.

Keywords: nanotechnology, drug delivery, bactericide, magnetic nanoparticles

\section{Introduction}

Iron oxide (IO) has been widely used in biomedical research because of its biocompatibility and magnetic properties. ${ }^{1,2}$ Nanoparticles of IO, with sizes less than $100 \mathrm{~nm}$, have been developed as contrast agents for magnetic resonance imaging (MRI), ${ }^{3,4}$ as hyperthermia agents, ${ }^{5,6}$ and as carriers for targeted drug delivery to treat several types of cancer. ${ }^{7,8}$ It is further believed that through the use of magnetic nanoparticles, an optimal drug delivery system can be developed by using an external magnetic field to direct such nanoparticles to desirable sites (such as implant infection) for immediate treatment ${ }^{9}$ (Figure 1).

Staphylococcus aureus is one of the most common human pathogens, and leads to many types of infection. ${ }^{10}$ This bacterium is responsible not only for local infections, such as wounds or postoperative infection, but also for prosthetic infection (such as through the use of catheters, endotracheal tubes, and other biomaterials). ${ }^{11-13}$ S. aureus is also known to possess an increasing ability to resist antibiotics ${ }^{14-16}$ (such as penicillin, methicillin, tetracycline, erythromycin, and vancomycin). Thus, it is necessary to find an alternative treatment (perhaps without the use of antibiotics) for S. aureus infection that is directed to the site of infection, localized, and difficult for bacteria to formulate resistance.

Along this line, some have hypothesized that reactive oxygen species (ROS) generated by $\mathrm{Fe}_{3} \mathrm{O}_{4}$ nanoparticles could kill bacteria without harming non-bacterial cells. ${ }^{17}$ Specifically, Pareta et al cultured osteoblasts (bone-forming cells) with IO nanoparticles (at a concentration of $4.25 \mathrm{mg} / \mathrm{mL}$ ) and found that cell density was greatly enhanced in the presence of IO nanoparticles compared with cells cultured without nanoparticles. ${ }^{9}$

Polyvinyl alcohol (PVA) is a polymer commonly used in biomedical applications because of its biocompatibility. ${ }^{18}$ IO nanoparticles stabilized by PVA were developed 


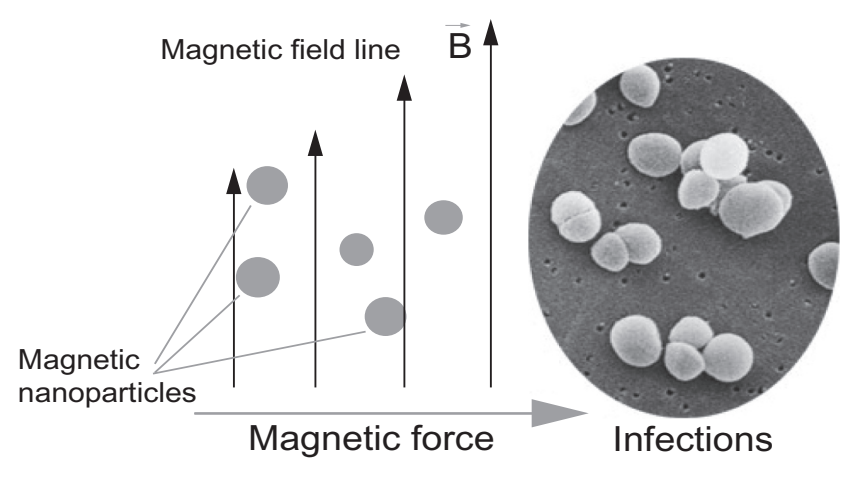

Figure I A simplified design for a magnetic drug delivery system in which magnetic nanoparticles coated with drugs are directed to infection sites by an external magnetic field.

in several studies focused on targeted drug delivery. ${ }^{19-21}$ In the present study, PVA was used as a matrix to deliver nonagglomerated nanoparticles, as suggested by previous researchers. ${ }^{22,23}$ The objectives of this study were to design, synthesize, and characterize PVA/IO nanoparticles and investigate the bactericidal activity of such nanoparticles when cultured with $S$. aureus.

\section{Materials and methods}

\section{Iron oxide nanoparticle synthesis}

IO nanoparticles were synthesized in situ via a matrixmediated method using PVA similar to previously suggested processes. ${ }^{24,25}$ Briefly, an aqueous solution of PVA (Acros Organics, Geel, Belgium) was mixed with equal volumes of ferrous/ferric aqueous solutions under ambient conditions. The iron-loaded PVA gels were soaked in stoichiometric amounts of warm aqueous solutions of $\mathrm{NaOH}$. The resulting ferrosoferric hydroxide dehydrates gave brownish precipitations in the polymer solution.

\section{Characterization of iron oxide/PVA}

A droplet of IO nanoparticles was placed on a transmission electron microscopy (TEM) copper grid and allowed to dry. The imaging was carried out at $100 \mathrm{kV}$ on a Philips EM420 TEM (Philips, Amsterdam, The Netherlands) and size calculations were carried out with ImageJ (version 1.42q; NIH, Bethseda, MD).

To measure the hydrodynamic size of the nanoparticles, $100 \mu \mathrm{L}$ of the particle solution was diluted with $1.5 \mathrm{~mL}$ of water and placed into a cuvette of a Zetasizer-nano instrument (Malvern, Philadelphia, PA). Experiments were conducted in triplicate to obtain an average number-size distribution. The same apparatus was used to measure zeta potentials.

X-ray diffraction (XRD) on dried IO nanoparticle powders was performed on a Siemens D500 (Siemens, Berlin, Germany) within a $2 \theta$ range of $20-80$ degrees using $\mathrm{Cu} \mathrm{K} \alpha$ radiation.
The magnetic properties of the dried nanoparticles were obtained using vibrating sample magnometry (VSM, LakeShore 7040) at room temperature.

\section{S. aureus culture}

$S$. aureus were obtained in frozen form from the American Type Culture Collection (ATCC; ATCC 25923). The bacteria were thawed on ice for 20 minutes before being plated on an agar plate. The plate was dried before incubation for 16 hours in a standard cell culture environment $\left(37^{\circ} \mathrm{C}, 5 \% \mathrm{CO}_{2}\right.$, and $95 \%$ air). A single colony of $S$. aureus was selected using a $10 \mu \mathrm{L}$ loop (Sigma, St. Louis, MO) and inoculated into centrifuge tubes containing $5 \mathrm{~mL}$ of tryptic soy broth. Bacteria in centrifuge tubes were then incubated at $37^{\circ} \mathrm{C}$ under agitation at $200 \mathrm{rpm}$ for another 16 hours. At that point, the bacteria solution was diluted in tryptic soy broth to an optical density of 0.52 at $562 \mathrm{~nm}$ using a microplate reader (SpectraMax300; Molecular Devices, Sunnyvale, CA). According to the standard curve correlating bacteria number with optical density, this value was equivalent to $5 \times 10^{6}$ cells $/ \mathrm{mL}$. The cells were further diluted in tryptic soy broth to $5 \times 10^{4}$ cells $/ \mathrm{mL}$ before being added to a new centrifuge tube at $3 \mathrm{~mL} /$ tubes.

Concentrated IO nanoparticles in solution were added to bacteria tubes at different doses $[30 \mu \mathrm{g} / \mathrm{mL}$ (low dose), $300 \mu \mathrm{g} / \mathrm{mL}$ (medium dose), and $3 \mathrm{mg} / \mathrm{mL}$ (high dose)]. A tube of bacteria without nanoparticles served as a control. The IO solution was also added to tubes containing only tryptic soy at the same concentration as above and this served as a particle control. Bacteria were then incubated under agitation for four hours, 12 hours, and 24 hours before a $200 \mu \mathrm{L}$ bacteria solution was transferred to a 96 -well plate for optical density readings at $562 \mathrm{~nm}$ using a microplate reader.

\section{S. aureus live/dead assay}

After four, 12, and 24 hours of incubation, $100 \mu \mathrm{L}$ of the bacteria suspension was transferred into a 96-well plate. A live/dead assay was performed according to manufacturer's instructions (Live/Dead BacLight, L7007; Invitrogen, Carlsbad, CA). Briefly, two solutions containing SYTO 9 dye and propidium iodide were mixed and diluted with double distilled water before being added to a bacteria solution at $100 \mu \mathrm{L} / w e l l$. The plate was incubated at room temperature in the dark for 15 minutes. Fluorescence intensities for live cells (excitation: $485 \mathrm{~nm}$, emission: $530 \mathrm{~nm}$ ) and dead cells (excitation: $485 \mathrm{~nm}$, emission: $630 \mathrm{~nm}$ ) were measured using a fluorescence microplate reader (SpectraMax M5; Molecular Devices). The two intensities were divided and reported as the ratio of live/dead bacteria. 


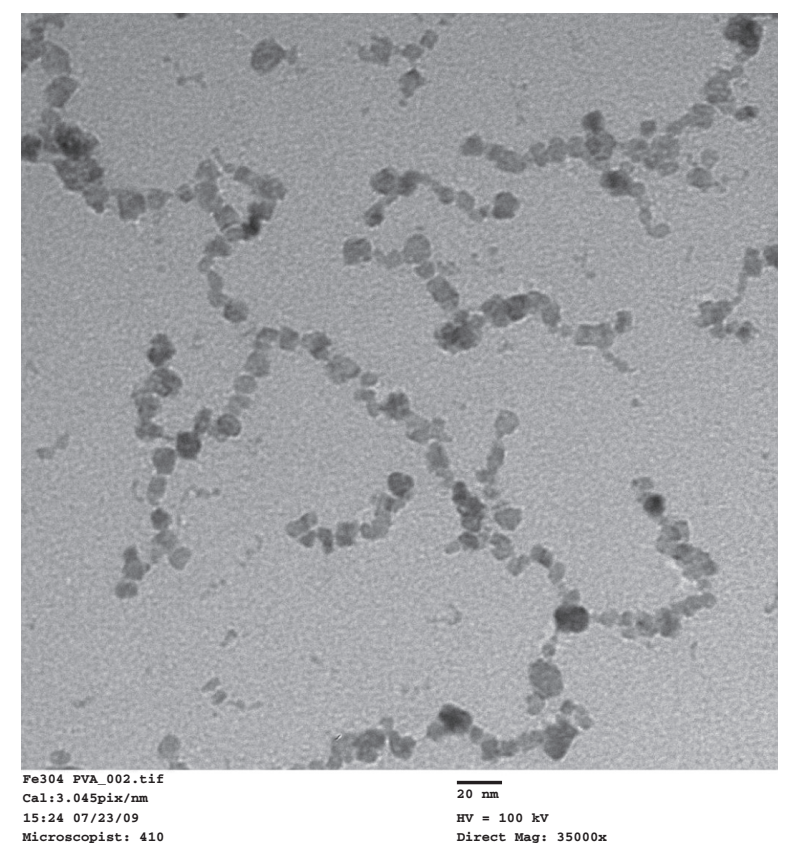

Figure 2 Transmission electron microscope images of the synthesized IO/PVA nanoparticles. Scale bar $=20 \mathrm{~nm}$.

Abbreviations: IO, iron oxide; PVA, polyvinyl alcohol.

\section{Statistical analysis}

All experiments were conducted in triplicate and repeated at least three times. Differences between means were determined using a Student's $t$-test.

\section{Results and discussion Nanoparticle synthesis and characterization}

TEM images of the synthesized PVA-coated IO nanoparticles (Figure 2) showed that the size of the nanoparticles was $9 \mathrm{~nm} \pm 4 \mathrm{~nm}$. The nanoparticles formed necklace-like chains with a typical length of approximately $100-200 \mathrm{~nm}$.
A similar formation was reported in an earlier study, in which IO nanoparticles were believed to precipitate along the polymer chain of PVA. ${ }^{22}$ The nanoparticle solution was a clear brownish color and no major types of aggregation were visible after months from synthesis.

The hydrodynamic diameter measurement results (Figure 3) showed that with the PVA coating, the IO chain-like particles had an average size of $140 \mathrm{~nm}$.

The measured average zeta potential was $-19 \mathrm{mV}$ (Figure 4). This low value suggested that the nanoparticle solution was stable mostly because of steric repulsion but not electrostatic repulsion. The long hydrophilic chains of the PVA associated with water molecules, thus, preventing agglomeration.

The XRD pattern confirmed that the final product was a mixture of $\mathrm{Fe}_{3} \mathrm{O}_{4}$ and $\gamma-\mathrm{Fe}_{2} \mathrm{O}_{3}$ (Figure 5). The existence of $\gamma-\mathrm{Fe}_{2} \mathrm{O}_{3}$ was common and was because of the oxidation of $\mathrm{Fe}_{3} \mathrm{O}_{4}$ during synthesis. ${ }^{26}$

According to the VSM results (Figure 6), the negligible coercivity of IO nanoparticles showed properties of superparamagnetic materials, meaning that these nanoparticles do not retain any magnetism after removal of a magnetic field. The high magnetization and superparamagnetic properties are highly desirable for biomedical applications because larger magnetic particles form aggregates after exposure to a magnetic field. ${ }^{2}$ The saturation magnetization of the synthesized IO nanoparticles was $15 \mathrm{emu} / \mathrm{g}$. As expected, because of the PVA coating saturation, magnetization of nanoparticles was lower than that of bulk phase magnetite $(\sim 90 \mathrm{emu} / \mathrm{g})$.

\section{Bactericidal activity of PVA-coated IO}

After four hours of incubation, the optical density measurements (Figure 7) showed that there was no significant difference in bacteria numbers in the presence of IO nanoparticles.

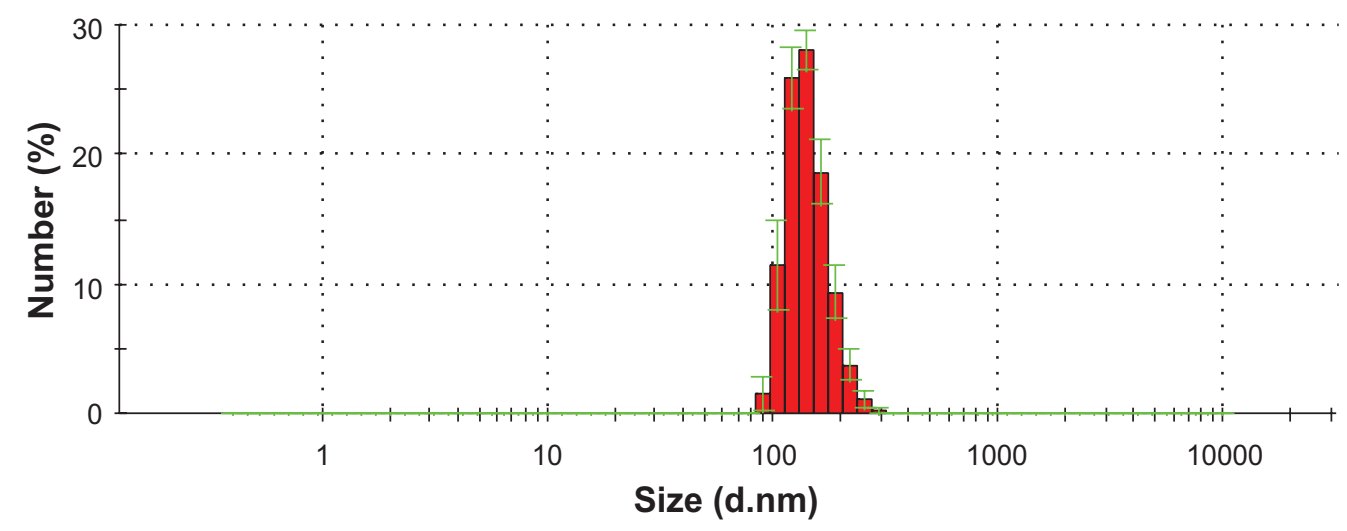

Figure 3 IO nanoparticle size distribution as measured by dynamic light scattering. Abbrevation: 10 , iron oxide. 


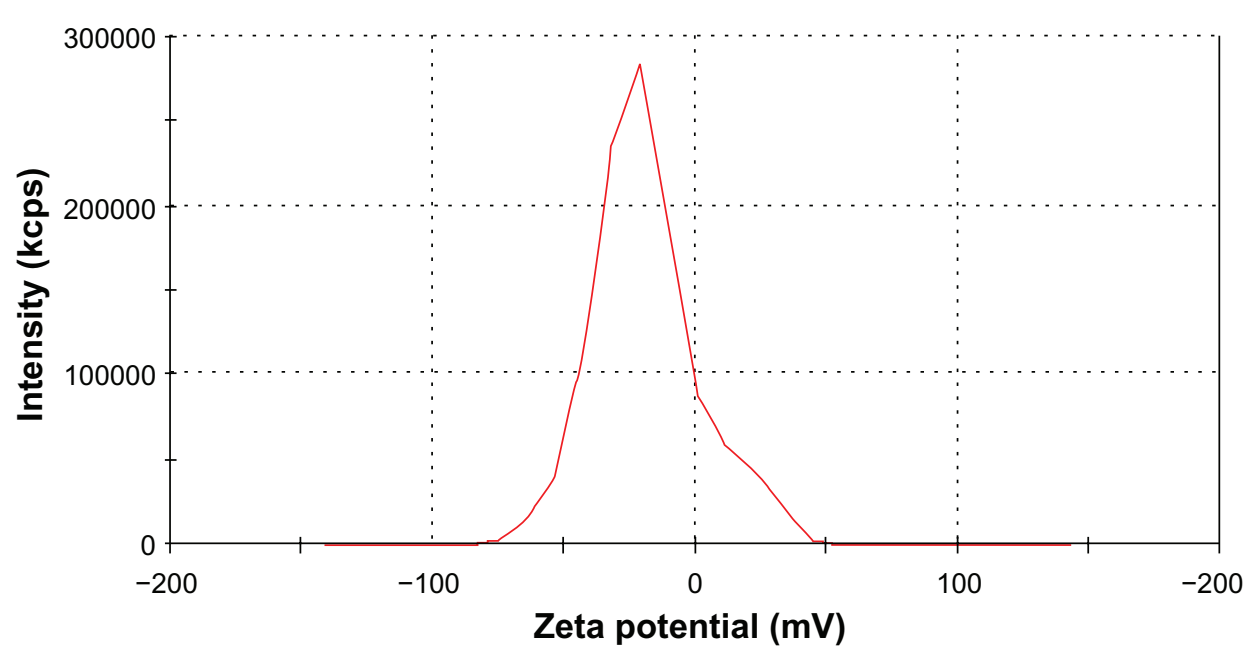

Figure 4 Zeta potential of $\mathrm{IO}$ nanoparticles in an aqueous solution was measured by a Malvern Zetasizer-nano instrument. Average zeta potential was - $19.09 \mathrm{mV}$. Abbreviation: $1 O$, iron oxide.

However, and more importantly, the results from the live/dead assay demonstrated that after four hours, the ratio of live/dead bacteria was significantly lower in the solution with the highest dose $(3 \mathrm{mg} / \mathrm{mL})$ of IO nanoparticles compared with the control sample as well as the low and medium dose samples; the same trend was observed after 12 hours and 24 hours (Figure 8).

There are several factors that caused the presently studied IO nanoparticles to be bactericidal. The main mechanism by which antibacterial drugs and antibiotics work is via oxidative stress generated by ROS. ${ }^{27}$ ROS, including superoxide radicals $\left(\mathrm{O}_{2}^{-}\right)$, hydroxyl radicals $(-\mathrm{OH})$, hydrogen peroxide $\left(\mathrm{H}_{2} \mathrm{O}_{2}\right)$, and singlet oxygen $\left({ }^{1} \mathrm{O}_{2}\right)$, can cause damage to proteins and DNA in bacteria. ${ }^{28}$ Park et al also demonstrated an antibacterial activity from silver metals because of ROS generation. ${ }^{29}$ In this case, metal oxide $\mathrm{Fe}_{3} \mathrm{O}_{4}$ could be the source that created ROS leading to the inhibition of S. aureus. A similar process was described by Keenan et al in which $\mathrm{Fe}^{2+}$ reacted with oxygen to create hydrogen peroxide. ${ }^{30}$ This $\mathrm{H}_{2} \mathrm{O}_{2}$ consequently reacted with ferrous irons via the Fenton

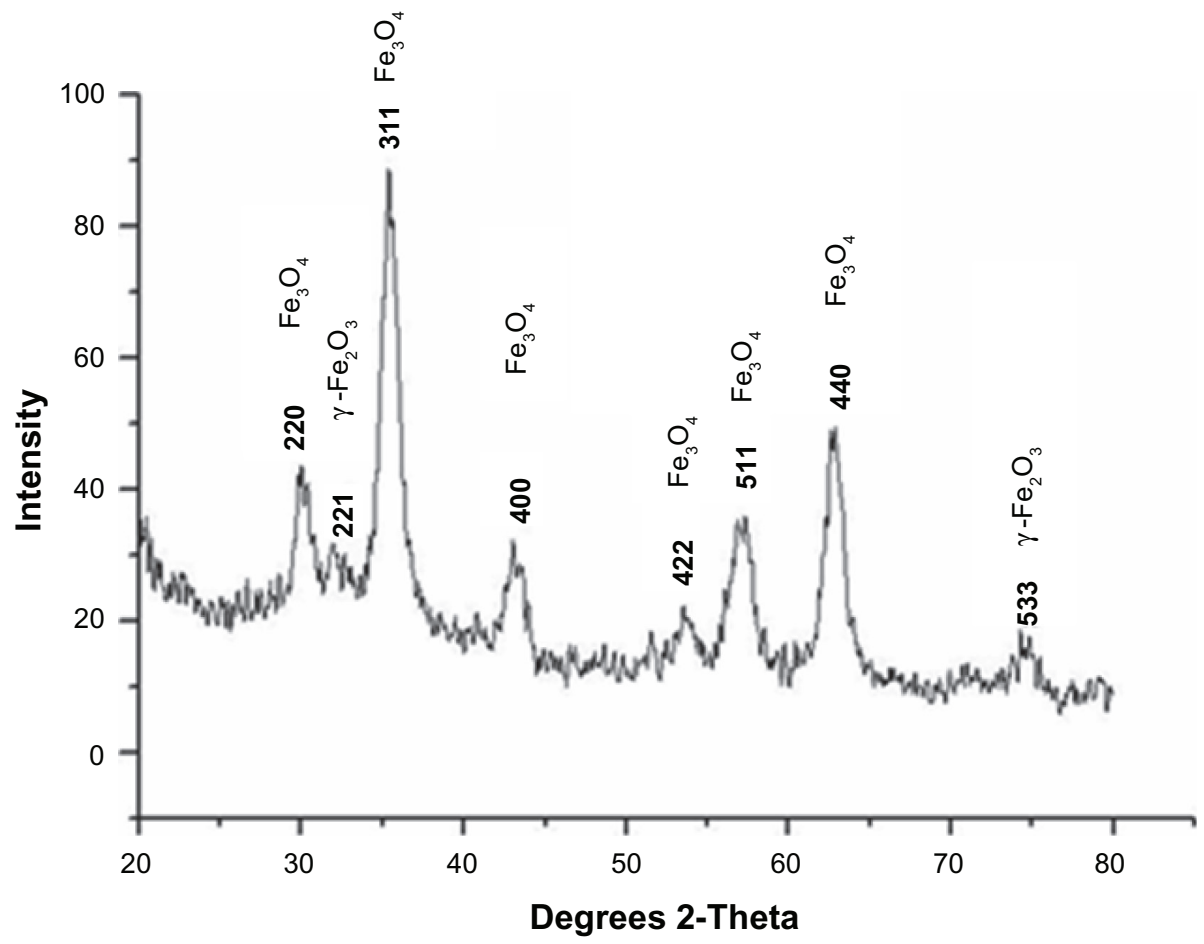

Figure 5 X-ray diffraction results of synthesized nanoparticles confirmed the existence of magnetite $\left(\mathrm{Fe}_{3} \mathrm{O}_{4}\right)$ and maghemite $\gamma$-Fe $\mathrm{O}_{3}$. 


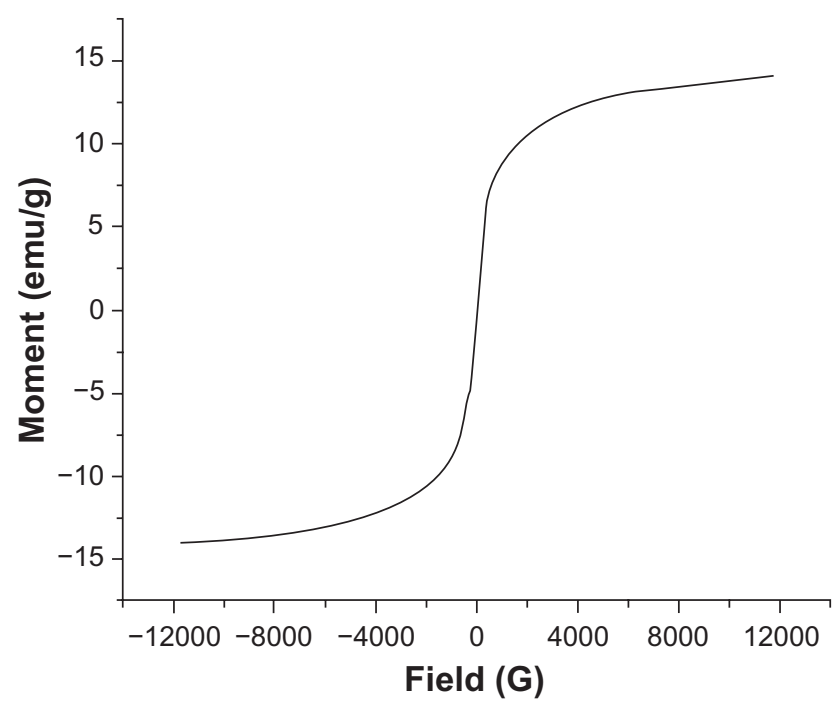

Figure 6 Magnetization curves of IO/PVA nanoparticles as measured by VSM at room temperature. The results clearly showed superparamagnetic behavior of the nanoparticles.

Abbreviations: IO, iron oxide; PVA, polyvinyl alcohol; VSM, vibrating sample magnometry.

reaction and produced hydroxyl radicals which are known to damage biological macromolecules. ${ }^{17}$

Other research has demonstrated that the small size of nanoparticles can also contribute to bactericidal effects. For example, Lee et al reported that the inactivation of Escherichia coli by zero-valent iron nanoparticles ${ }^{31}$ could be because of the penetration of the small particles (sizes ranging from 10-80 nm) into E. coli membranes.
Nano- $\mathrm{Fe}^{0}$ could then react with intracellular oxygen, leading to oxidative stress and eventually causing disruption of the cell membrane. Several other studies on $\mathrm{ZnO}$ and $\mathrm{MgO}$ nanoparticles also concluded that antibacterial activity increased with decreasing particle size. ${ }^{32-34}$

In this study, the concentration of nanoparticles was a major contribution to $S$. aureus activity inhibition. A similar concentration-dependent behavior was observed by Kim et al when they investigated the antimicrobial effects of $\mathrm{Ag}$ and $\mathrm{ZnO}$ nanoparticles on S. aureus and E. coli. . $^{32,35}$ In a study of bactericidal effects of IO nanoparticles on $S$. epidermidis, Taylor et al also reported concentrationdependent bacteria inhibition. ${ }^{36}$ Briefly, S. epidermidis density progressively decreased at time points of 12,24 , and 48 hours when incubated with $100 \mu \mathrm{g} / \mathrm{mL}, 1 \mathrm{mg} / \mathrm{mL}$, and $2 \mathrm{mg} / \mathrm{mL}$ IO.

It is also important to note that IO nanoparticles do not negatively influence all cells. Specifically, osteoblast (boneforming cell) proliferation was enhanced in the presence of $\mathrm{Fe}_{2} \mathrm{O}_{3}$ nanoparticles (at $4.25 \mathrm{mg} / \mathrm{mL}$, the same order of magnitude which inhibited bacteria in this study). ${ }^{9}$ Such results showed that IO nanoparticles could have a dual therapeutic function which can enhance bone growth and inhibit bacteria infection. Lastly, this present study provided evidence that with an appropriate external magnetic field, IO magnetic particles may be directed to kill bacteria as needed throughout the body.

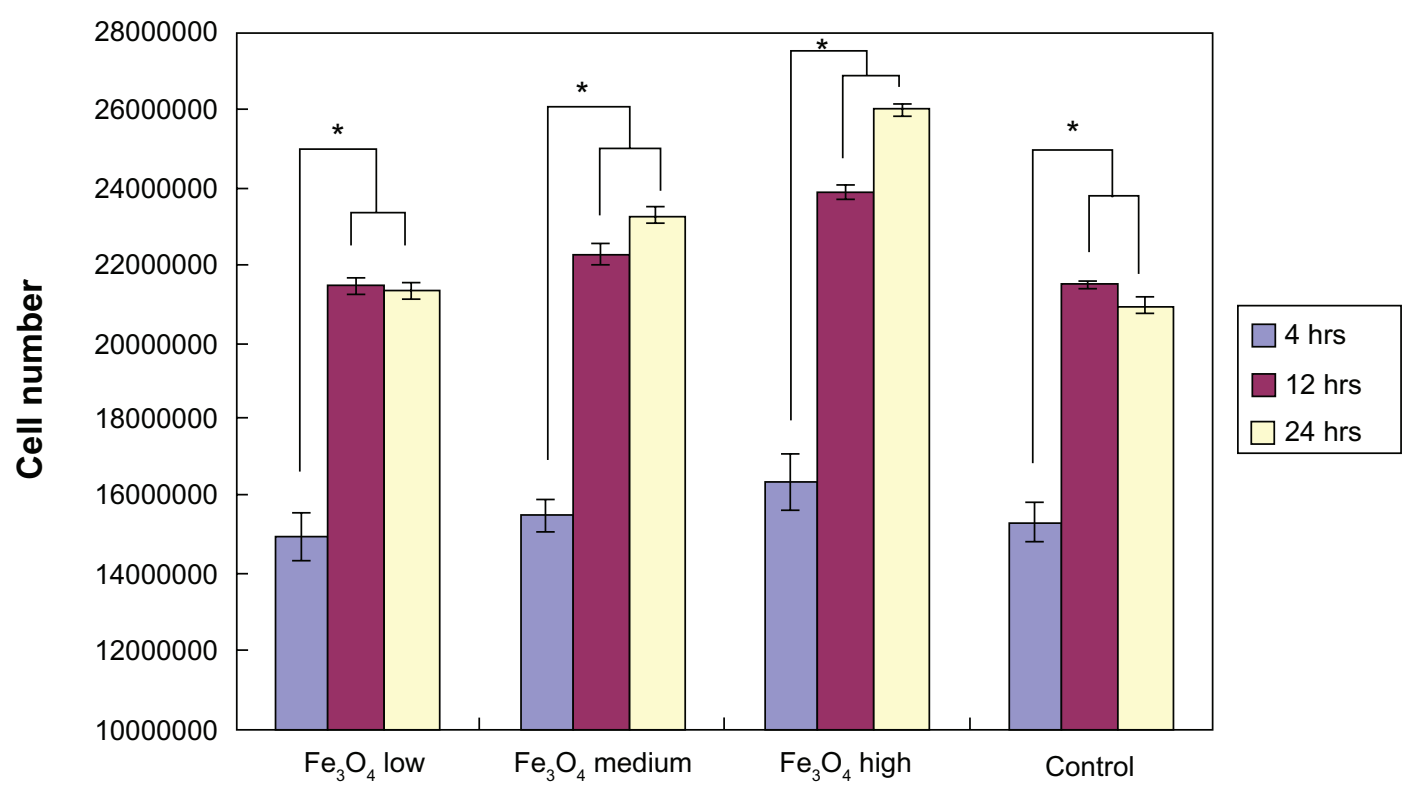

Figure 7 Optical density reading of bacteria in IO/PVA solution after four hours, 12 hours, and 24 hours. The results are mean \pm SEM. ( $\mathrm{n}=3$ ). All densities are significantly $(* P<0.0 I)$ greater at 12 and 24 hours compared with the four-hour time point.

Abbreviations: IO, iron oxide; PVA, polyvinyl alcohol. 
A

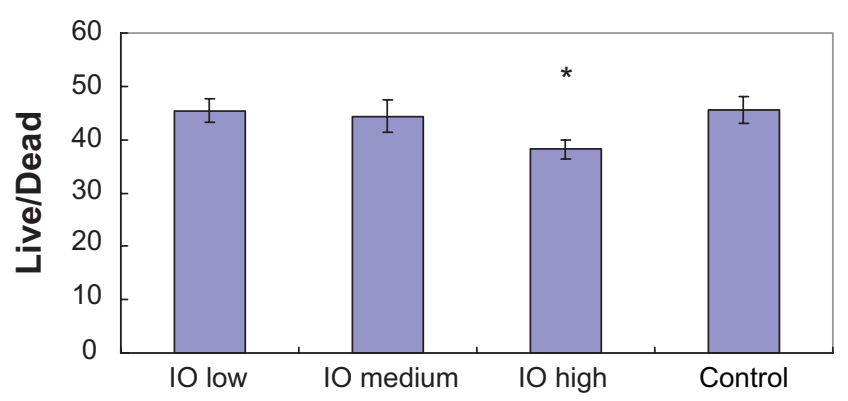

B

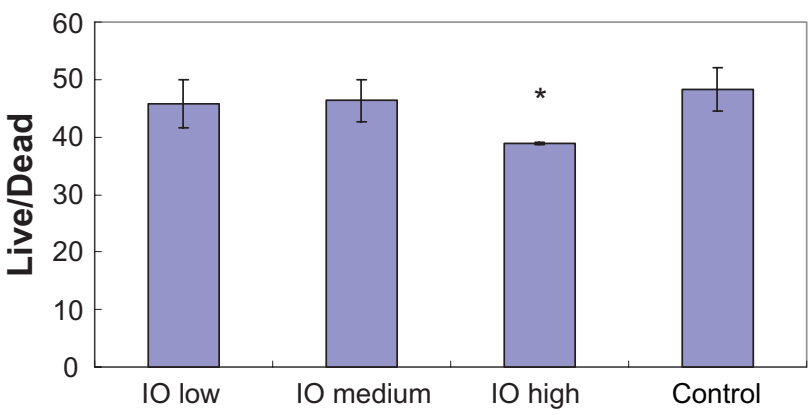

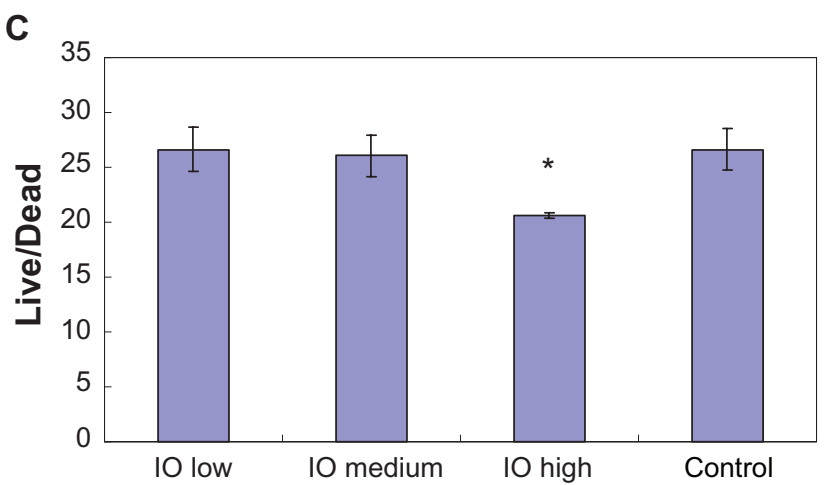

Figure 8 Live/dead assay results showed lower live/dead ratios in the presence of the high dose ( $3 \mathrm{mg} / \mathrm{mL})$ IO/PVA nanoparticle solution after incubation for A) four hours, B) 12 hours, and C) 24 hours. Data $=$ mean \pm SEM; $\mathrm{n}=3$. $* P<0.05$ compared with control sample and samples with low $(30 \mathrm{mg} / \mathrm{mL}) \mathrm{and} \mathrm{medium} \mathrm{doses}(300 \mathrm{mg} / \mathrm{mL})$ of $1 \mathrm{O}$ nanoparticles.

Abbreviations: IO, iron oxide; PVA, polyvinyl alcohol.

\section{Conclusions}

Stable IO/PVA nanoparticles were successfully synthesized. The particles were characterized with TEM, dynamic light scattering, XRD and VSM. A live/dead assay showed that at the highest dose of iron oxide $(3 \mathrm{mg} / \mathrm{mL})$, the growth of $S$. aureus was inhibited significantly compared with the control samples. Further studies should investigate the bactericidal effect of iron oxide nanoparticles on other types of bacteria for potentially widening such antibacterial applications.

\section{Acknowledgments}

The authors thank the Hermann Foundation, Vietnam Education Foundation, and the Indo-US Center for Biomaterials for Healthcare for funding.

\section{Disclosure}

The authors report no conflict of interest in this work.

\section{References}

1. Gupta AK, Gupta M. Synthesis and surface engineering of iron oxide nanoparticles for biomedical applications. Biomaterials. 2005;26(18):3995-4021.
2. Berry CC, Curtis ASG. Functionalisation of magnetic nanoparticles for applications in biomedicine. J Phys D Appl Phys. 2003;36: R198-R206.

3. Beets-Tan RGH, Van Engelshoven JMA, Greve JWM. Hepatic adenoma and focal nodular hyperplasia: MR findings with superparamagnetic iron oxide- enhanced MRI. Clin Imaging. 1998;22(3): 211-215.

4. Babes L, Denizot B, Tanguy G, Le Jeune JJ, Jallet P. Synthesis of iron oxide nanoparticles used as MRI contrast agents: A parametric study. J Colloid Interface Sci. 1999;212(2):474-482.

5. Chan DCF, Kirpotin DB, Bunn PA. Synthesis and evaluation of colloidal magnetic iron oxides for the site-specific radiofrequencyinduced hyperthermia of cancer. J Magn Mag Mat. 1993;122(1-3): 374-378.

6. Gonzales-Weimuller M, Zeisberger M, Krishnan KM. Size-dependent heating rates of iron oxide nanoparticles for magnetic fluid hyperthermia. J Magn Mag Mat. 2009;321(13):1947-1950.

7. Chertok B, Moffat BA, David AE, et al. Iron oxide nanoparticles as a drug delivery vehicle for MRI monitored magnetic targeting of brain tumors. Biomaterials. 2008;29(4):487-496.

8. Kohler N, Sun C, Wang J, Zhang M. Methotrexate-modified superparamagnetic nanoparticles and their intracellular uptake into human cancer cells. Langmuir. 2005;21(19):8858-8864.

9. Pareta RA, Taylor E, Webster TJ. Increased osteoblast density in the presence of novel calcium phosphate coated magnetic nanoparticles. Nanotechnology. 2008;19(26):265101.

10. Grinholc M, Szramka B, Kurlenda J, Graczyk A, Bielawski KP. Bactericidal effect of photodynamic inactivation against methicillinresistant and methicillin-susceptible Staphylococcus aureus is strain-dependent. J Photochem Photobiol A Chem. 2008;90(1): $57-63$. 
11. Michael CH, Warren KR, Kelly PF. Staphylococcus aureus adhesion to bone matrix and bone-associated biomaterials. FEMS Microbiol Lett. 1999;173(2):279-284.

12. Mariusz G, Grzegorz W, Julianna K. Evaluation of biofilm production and prevalence of the icaD gene in methicillin-resistant and methicillin-susceptible Staphylococcus aureus strains isolated from patients with nosocomial infections and carriers. FEMS Immunol Med Microbiol. 2007;50(3):375-379.

13. Harris LG, Tosatti S, Wieland M, Textor M, Richards RG. Staphylococcus aureus adhesion to titanium oxide surfaces coated with non-functionalized and peptide-functionalized poly(-lysine)grafted-poly(ethylene glycol) copolymers. Biomaterials. 2004;25(18): 4135-4148.

14. Jevons MP. “Celbenin”-resistant Staphylococci. BMJ. 1961;1(5219): 124-125.

15. Hiramatsu K. Vancomycin-resistant Staphylococcus aureus: A new model of antibiotic resistance. Lancet Infect Dis. 2001;1(3):147-155.

16. Chambers HF. The changing epidemiology of Staphylococcus aureus? Emerg Infect Dis. 2001;7(2):178-182.

17. Touati D. Iron and oxidative stress in bacteria. Arch Biochem Biophys. 2000;373(1):1-6.

18. Albornoz C, Jacobo SE. Preparation of a biocompatible magnetic film from an aqueous ferrofluid. J Magn Mag Mat. 2006;305(1):12-15.

19. Chastellain M, Petri A, Hofmann H. Particle size investigations of a multistep synthesis of PVA coated superparamagnetic nanoparticles. $J$ Colloid Interface Sci. 2004;278(2):353-360.

20. Xu C, Teja AS. Continuous hydrothermal synthesis of iron oxide and PVA-protected iron oxide nanoparticles. J Supercritical Fluids. 2008;44:85-91.

21. Petri-Fink A, Chastellain M, Juillerat-Jeanneret L, Ferrari A, Hofmann H. Development of functionalized superparamagnetic iron oxide nanoparticles for interaction with human cancer cells. Biomaterials. 2005;26(15):2685-2694.

22. Pardoe H, Chua-anusorn W, St. Pierre TG, Dobson J. Structural and magnetic properties of nanoscale iron oxide particles synthesized in the presence of dextran or polyvinyl alcohol. J Magn Mag Mat. 2001;225(1-2):41-46.

23. Schöpf B, Neuberger T, Schulze K, et al. Methodology description for detection of cellular uptake of PVA coated superparamagnetic iron oxide nanoparticles (SPION) in synovial cells of sheep. J Magn Mag Mat. 2005;293(1):411-418.
24. Sinha A, Nayar S, Murthy GVS, Joy PA, Rao V, Ramachandrarao P. Biomimetic synthesis of superparamagnetic iron oxide particles in proteins. J Mater Res. 2003;18(6):1309-1313.

25. Sinha A, Nayar S, Nath BK, Das D, Mukhopadhyay PK. Magnetic field induced synthesis and self-assembly of super paramagnetic particles in a protein matrix. Colloids Surf B Biointerfaces. 2005;43(1):7-11.

26. Cannas C, Gatteschi D, Musinu A, Piccaluga G, Sangregorio C. Structural and magnetic properties of $\mathrm{Fe}_{2} \mathrm{O}_{3}$ nanoparticles dispersed over a silica matrix. J Phys Chem B. 1998;102(40):7721-7726.

27. Kohanski MA, Dwyer DJ, Hayete B, Lawrence CA, Collins JJ. A common mechanism of cellular death induced by bactericidal antibiotics. Cell. 2007;130(5):797-810.

28. Sies H. Oxidative stress: oxidants and antioxidants. Exp Physiol. 1997;82(2):291-295.

29. Park HJ, Kim JY, Kim J, et al. Silver-ion-mediated reactive oxygen species generation affecting bactericidal activity. Water Res. 2009;43(4):1027-1032.

30. Keenan CR, Sedlak DL. Factors affecting the yield of oxidants from the reaction of nanoparticulate zero-valent iron and oxygen. Environ Technol. 2008;42(4):1262-1267.

31. Lee C, Kim JY, Lee WI, Nelson KL, Yoon J, Sedlak DL. Bactericidal effect of zero-valent iron nanoparticles on Escherichia coli. Environ Technol. 2008;42(13):4927-4933.

32. Zhang L, Jiang Y, Ding Y, Povey M, York D. Investigation into the antibacterial behaviour of suspensions of $\mathrm{ZnO}$ nanoparticles ( $\mathrm{ZnO}$ nanofluids). J Nanopart Res. 2007;9(3):479-489.

33. Yamamoto O. Influence of particle size on the antibacterial activity of zinc oxide. Inter J Inorg Mater. 2001;3(7):643-646.

34. Makhluf S, Dror R, Nitzan Y, Abramovich Y, Jelinek R, Gedanken A. Microwave-assisted synthesis of nanocrystalline $\mathrm{MgO}$ and its use as a bacteriocide. Adv Funct Mater. 2005;15(10):1708-1715.

35. Kim JS, Kuk E, Yu KN, et al. Antimicrobial effects of silver nanoparticles. Nanomed Nanotechnol Biol Med. 2007;3(1):95-101.

36. Taylor EN, Webster TJ. The use of superparamagnetic nanoparticles for prosthetic biofilm prevention. Int J Nanomedicine. 2009;4:145-152.
International Journal of Nanomedicine

\section{Publish your work in this journal}

The International Journal of Nanomedicine is an international, peerreviewed journal focusing on the application of nanotechnology in diagnostics, therapeutics, and drug delivery systems throughout the biomedical field. This journal is indexed on PubMed Central,

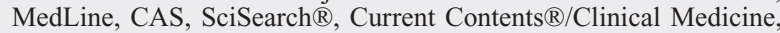

\section{Dovepress}

Journal Citation Reports/Science Edition, EMBase, Scopus and the Elsevier Bibliographic databases. The manuscript management system is completely online and includes a very quick and fair peer-review system, which is all easy to use. Visit http://www.dovepress.com/ testimonials.php to read real quotes from published authors. 